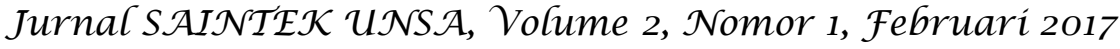

\title{
KAJIAN POTENSI AIR TANAH DENGAN PENGUJIAN GEOLISTRIK DI DESA TELONANG KABUPATEN SUMBAWA BARAT
}

\author{
ADY PURNAMA ${ }^{1}$ ADRIAN NOVAL ${ }^{2}$ \\ Dosen Program Studi Teknik Sipil Fakultas Teknik Universitas Samawa Sumbawa Besar ${ }^{1}$ \\ Mahasiswa Program Studi Teknik Sipil Fakultas Teknik Universitas Samawa Sumbawa Besar ${ }^{2}$
}

\begin{abstract}
ABSTRAK
Ketersediaan air bersih yang mulai menipis ditambah dengan kondisi lahan atau wilayah yang mengalami kekeringan, maka dituntut untuk mencari suatu solusi dan salah satu solusi yang bisa direalisasikan adalah mencari sumber potensi air tanah untuk memenuhi kebutuhan air bersih masyarakat. Berdasarkan permasalahan akan kebutuhan air bersih yang terjadi di Kabupaten Sumbawa Barat, maka cukup layak diangkat suatu penelitian yang nantinya diharapkan bisa menjawab permasalahan masyarakat Kabupaten Sumbawa Barat akan ketersediaan air bersih. Adapun tujuan penelitian ini adalah mengetahui potensi akuifer untuk pemanfaatan air tanah melalui sumur dalam.

Penelitian ini merupakan penyelidikan air tanah dengan sistem pengukuran lapangan yang dilakukan di Desa Telonang Kabupaten Sumbawa Barat. Pengujian ini dilakukan dengan menggunakan metode Geolistrik Resistivitas dengan jumlah titik penyelidikan adalah 9 titik yang dibagi dalam 3 zona. Adapun tahapan penyelidikan adalah dimulai dari tahap persiapan, tahap survey lapangan, dan tahap analisis dan interpretasi data dengan menggunakan software IPI2Win.

Hasil penelitian menunjukkan Zona 1 (Dusun A) batuan yang berpotensi sebagai akuifer adalah pasir tufaan dengan titik pengukuran 3 adalah lokasi yang memiliki potensi lebih besar dari pada titik lainnya. Karakteristik akuifer didaerah ini adalah akuifer setempat yang dipengaruhi oleh musim. Zona 2 (Dusun B) batuan yang berpotensi sebagai akuifer adalah pasir tufaan dengan titik pengukuran 3 adalah lokasi yang memiliki potensi lebih besar dari pada titik lainnya. Karakteristik akuifer didaerah ini adalah akuifer setempat yang dipengaruhi oleh musim. Zona 3 (Dusun C) batuan yang berpotensi sebagai akuifer adalah pasir tufaan dengan titik pengukuran 2 adalah lokasi yang memiliki potensi lebih besar dari pada titik lainnya. Karakteristik akuifer didaerah ini adalah akuifer setempat yang dipengaruhi oleh musim.
\end{abstract}

Kata Kunci : Air Tanah, Potensi, Telonang, Pengujian Geolistrik, Software IPI2Win.

\section{PENDAHULUAN}

Kabupaten Sumbawa Barat (KSB) adalah salah satu kabupaten di wilayah Pulau Sumbawa, merupakan Kabupaten baru hasil dari pemekaran dari Kabupaten Sumbawa, terletak diujung barat pulau Sumbawa pada posisi 116" 42' sampai dengan 117" 05' BT dan 08" 30' sampai dengan 09" 07' LS. Secara geografis, wilayah Kabupaten Sumbawa Barat dan sekitarnya tergolong daerah kering dimana musim basah (hujan) lebih pendek (4 5) bulan dibandingkan musim kering (kemarau). Perubahan iklim yang ditandai dengan peningkatan suhu, diperkirakan akan menurunkan curah hujan di wilayah yang cenderung kering dan meningkatkan curah hujan di wilayah curah. Dusun Talonang adalah salah satu Dusun yang berada pada Kecamatan Sekongkang-KSB, yang terletak diujung selatan KSB dan merupakan daerah perbatasan antara KSB dan Kabupaten Sumbawa. Daerah ini merupakan daerah transmigrasi yanag telah dibuka sekitar tahun 2010, dimana awalnya merupakan kawasan hutan non produktif. Mengingat daerah ini digolongkan daerah baru berpenghuni, ketersedian sarana dan prasarana masih tergolong minim. Khususnya dalam penyedian air baku guna keperluan sehari-hari, karena saat ini sebagian besar masyarakat memanfaatkan air baku harus mengambil langsung dari sungai. Pemanfaatan air tanah melalui pengembangan sumur dalam merupakan salah satu alternatif dalam 


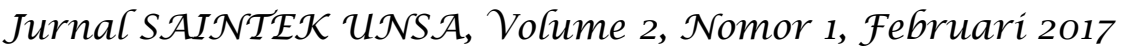

penyediaan kebutuhan air baku bagi masyarakat yang belum atau tidak bisa dijangkau oleh air permukaan. Akan tetapi, keberadaan air tanah sangatlah bervariasi dan tidak menyebar rata, tergantung pada topografi, geologi bawah permukaan (lapisan pembawa / aquifer), dan sejarah geologi setiap wilayah. Informasi tentang geologi bawah permukaan merupakan salah satu aspek penting dalam mencari air tanah. Informasi ini meliputi struktur geologi (lipatan, patahan, rekahan), jenis dan sifat fisis batuan. Susunan batuan di bawah permukaan, kedalaman, ketebalan dan distribusinya, termasuk kondisi akuifer pengandung air tanah. Salah satu cara untuk bisa mengetahui kondisi bawah permukaan tersebut adalah melakukan pengukuran geofisika dengan metode geolistrik resistivity (tahanan jenis).

Berdasarkan permasalahan akan kebutuhan air bersih yang terjadi di Desa Telonang, maka cukup layak diangkat suatu penelitian yang berjudul "Kajian Potensi Air Tanah Dengan Pengujian Geolistrik Di Desa Telonang Kabupaten Sumbawa Barat". Penelitian ini nantinya diharapkan bisa menjawab permasalahan masyarakat Desa Telonang akan ketersediaan air bersih.

\section{METODOLOGI PENELITIAN}

Kabupaten Sumbawa Barat sebagai salah satu daerah dari sembilan kabupaten/kota yang berada di wilayah Propinsi Nusa Tenggara Barat terletak diujung barat pulau Sumbawa pada posisi 116" 42' sampai dengan 117" 05' BT dan 08" 30' sampai dengan 09" $07^{\prime}$ LS, dengan batas-batas wilayah sebagai berikut : Sebelah Utara adalah Kec. Alas Barat dan Kec. Alas Kabupaten Sumbawa, Sebelah Timur adalah Kec. Batu Lanteh dan Kec. Lunyuk Kab. Sumbawa, Sebelah Selatan adalah Samudera Indonesia dan Sebelah Barat adalah Selat Alas. Wilayah daratan KSB tahun 2009 seluas $1.849,02 \mathrm{~km}^{2}$ atau 184.902 ha yang tersebar pada delapan kecamatan dengan 57 desa dan enam kelurahan, seperti disajikan pada Tabel 1.berikut.
Tabel 1. Luas Wilayah Daratan KSB menurut Kecamatan

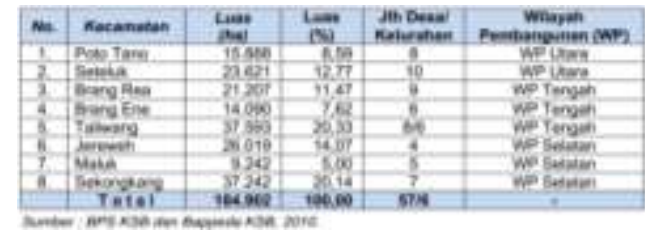

Kabupaten Sumbawa Barat mempunyai iklim tropis basah dan dipengaruhi oleh pergantian angin muson barat laut dan angin muson tenggara.Angin muson tenggara yang kering mengakibatkan terjadinya musim kemarau (umumnya terjadi bulan April sampai Oktober) dan angin muson barat laut yang basah menyebabkan musim hujan (umumnya terjadi pada bulan Nopember sampai dengan bulan Maret) dengan sifat hujan umumnya dibawah normal (B).Curah hujan rata-rata tahunan di Kabupaten Sumbawa Barat adalah $1.000 \mathrm{~s} / \mathrm{d} 2.000 \mathrm{~mm}$.

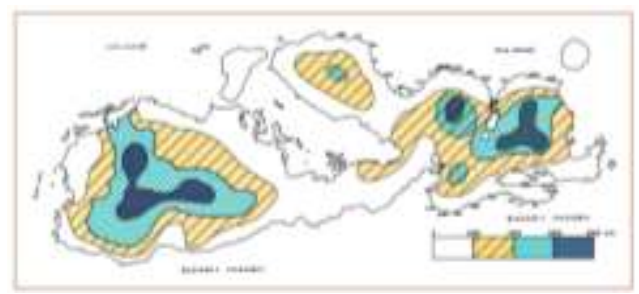

Gambar 1. Peta Curah Hujan di

Pulau Sumbawa (Kusmajaya F, 2015)

Keadaan topografi wilayah KSB cukup beragam, mulai dari datar, bergelombang curam sampai sangat curam dengan ketinggian berkisar antara 0 hingga 1.730 meter dari permukaan laut (mdpl) seperti disajikan pada Tabel 2.

Tabel 2. Keadaan Topografi Wilayah KSB Tahun 2009

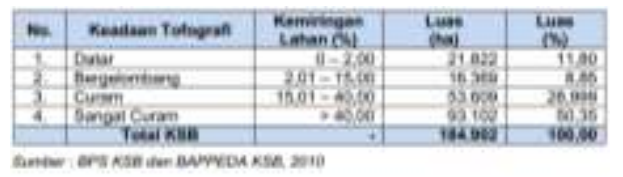

Ketinggian ibukota pada setiap kecamatan di KSB berkisar antara 7 sampai $31 \mathrm{mdpl}$. Topografi yang semakin datar dan bergelombang sebagian besar 


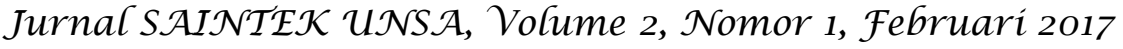

digunakan untuk lokasi permukiman dan lahan pertanian, sedang topografi yang semakin curam hingga sangat curam sebagian besar merupakan kawasan hutan yang berfungsi untuk melindungi kawasan sekitarnya yang lebih rendah.

\section{Lokasi Penelitian}

Adapun lokasi penelitian berada di Pulau Sumbawa yaitu Kabupaten Sumbawa Barat, Kecamatan Sekongkang, Dusun Talonang, dengan jumlah titik penyelidikan adalah 9 (sembilan) titik yang dibagi dalam 3 (tiga) zona.

Tabel 3. Lokasi Kegiatan

Penyelidikan Geolistrik

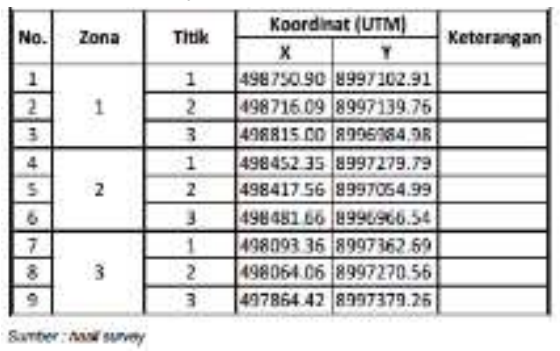

Kerangka Pikir Penelitian

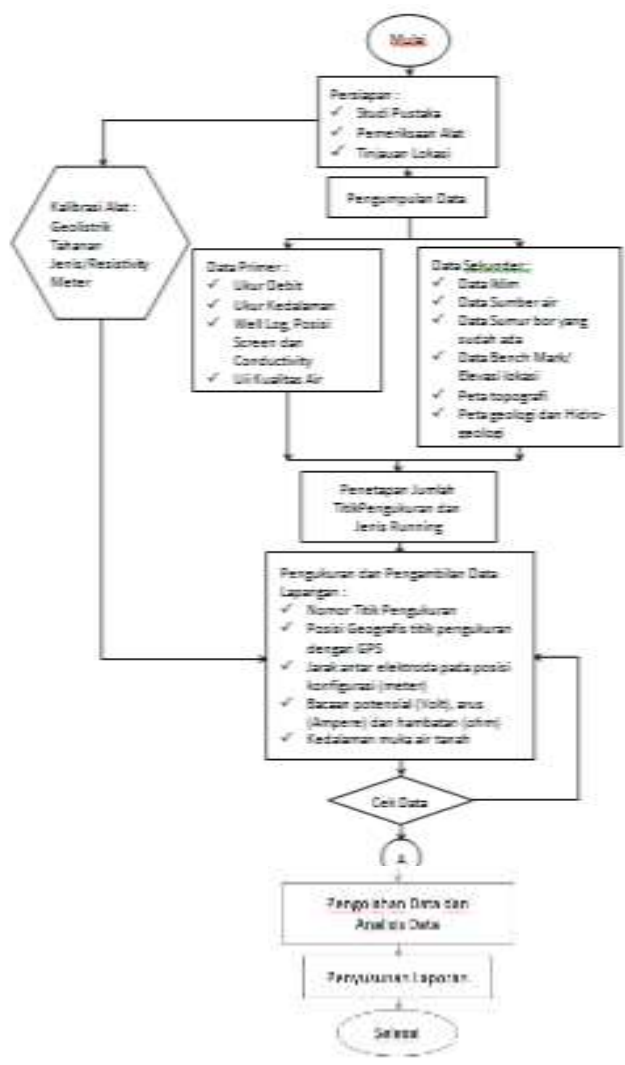

Tahapan Pelaksanaan Penelitian

Untuk mencapai tujuan dan hasil terbaik, pelaksanaan penelitian ini dibagi dalam beberapa tahap.

Tahap Persiapan

Pada tahap ini disusun rencana kerja yang lebih terinci dan mulai memberikan penugasan kepada personil-personil yang akan ditugaskan dalam kegiatan ini. Pekerjaan persiapan merupakan tahap kegiatan awal yang bermaksud untuk menunjang tahapan berikutnya, yaitu pekerjaan lapangan sehingga seluruh pekerjan ini dapat dilaksanakan sesuai dengan yang diharapkan. Pada tahap ini kegiatan yang dilakukan diperlukan untuk memperlancar kegiatan penyelidikan lapangan dan analisisnya. Kegiatan tahap persiapan meliputi pengumpulan data sekunder dan penyiapan peralatan kerja.

a.Penyusunan Rencana Kerja dan Formulir Survey

Berdasarkan evaluasi dan analisis terhadap data sekunder yang telah diperoleh, diharapkan pelaksana dapat menyusun Rencana Kerja sehingga seluruh ruang lingkup pekerjaan ini dapat diselesaikan dengan baik dalam kurun waktu seefisien mungkin. Sebelum mobilisasi peralatan dan personil ke lapangan, konsultan harus menyiapkan format data dan kurva tahanan jenis semu (apperent resistivity).

b.Pengumpulan data

Kegiatan ini dimaksudkan untuk memperoleh informasi teknis yang berkaitan dengan air tanah yaitu publikasi yang menyangkut kondisi topografi, geologi, hidrogeologi, photo udara, geofisika serta data sumur bor (debit, kedalaman, well log, posisi screen, conductivity dan kualitas air) di daerah penyelidikan. Publikasi-publikasi tersebut umumnya dari instansi Pemerintah dan Swasta seperti : Pendayagunaan Air Tanah (PAT II) - BWS NT I, 


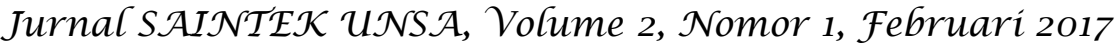

Direktorat Geologi Tata Lingkungan (DGTL) Bandung, LAPI-ITB Bandung, Dinas Pertambangan dan Energi, Perusahaan pengebor ABT dan PDAM. Pengumpulan data sekunder atau pendukung yang diperlukan dari berbagai sumber instansi:

1) Data iklim meliputi curah hujan, temperatur dan sebagainya.

2) Data sumber air dan daerah isian.

3) Data sumur bor yang sudah ada.

4) Data Bench Mark/elevasi lokasi di sekitar daerah proyek.

5) Peta-peta topografi, peta geologi dan hidrogeologi daerah proyek.

Data-data tersebut selanjutnya dianalisa dan dijadikan sebagai referensi atau acuandalam penentuan perlapisan batuan yang kemudian dijadikan dasar untuk menentukan aquifer dari perlapisan batuan tersebut.

c. Mobilisasi peralatan kerja

Peralatan yang harus disiapkan antara lain Unit Resistivity Survey, alat-alatpencatat data, alat hitung, meteran dan lain-lain. Peralatan tersebut perlu diperiksadan disetujui oleh Direksi tentang kondisi dan ketelitiannya, agar hasil pelaksanaan pekerjaan sesuai dengan persyaratan ketelitian yang ditentukan serta hasilnya baik. Apabila selama pengukuran lapangan terjadi masalah pada unit peralatan dan perbaikannya membutuhkan lebih dari 24 jam, maka atas perintah Direksi, Konsultan harus mendatangkan peralatan pengganti dengan segera yang mempunyai fungsi dan spesifikasi sesuai dengan ketentuan.

Alat-alat untuk penelitian Geolistrik Resistivitas adalah :

1) Geolistrik Tahanan Jenis/Resistivity Meter

2) Elektroda Potensial (Terbuat dari tembaga)

3) Baterai basah (Aki) 12 Volt 6Ah

4) Palu/hammer

5) Kabel roll dan Patok

6) HT Motorolla
7) GPS

8) Laptop dan Charger

9) Alat pendukung lainnya : alat tulis, payung, dll

Adapun bentuk atau model alat survey geolistrik resistivitas dapat dilihat pada gambar 2 dibawah ini.

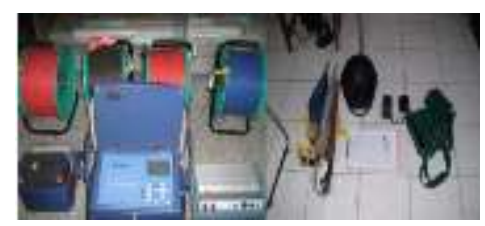

Gambar 2. Peralatan Survey Geolistrik dan Perlengkapannya (Foto Pribadi, 2016)

\section{Tahap Survey Lapangan}

Pada tahap ini dilakukan pengukuran geolistrik di Dusun Talonang serta dilakukan pengamatan posisi geografis titik-titik pengukuran geolistrik dengan menggunakan handy Global Positioning System (GPS). Selain itu juga dilakukan pengamatan tinggi muka air penduduk. Tahapan pekerjaan lapangan meliputi beberapa hal, diantaranya adalah :

a. Recognise/ Orientasi Lapangan antara lain :

1) Menyiapkan peralatan dan kendaraan untuk survey

2) Koordinasi dengan pemberi kerjaan

b. Investigasi Kondisi Geologi, Hidrogeologi dan Pembuatan Rencana Titik Pengukuran Geolistrik

Kajian geologi dimaksudkan untuk mengetahui kondisi penyebaran litologi, singkapan batuan, kemiringan dan arah lapisan batuan (strike dan dip) serta struktur geologi secara lokal. Adapun kajian hidrgeologi dimaksudkan untuk mengetahui aspek yang berhubungan dengan potensi air tanah dan penyebaranya. Kedua kajian di atasdipakai sebagai acuan sebelum dilakukan pengukuran geolistrik dan sebagai dasar awal untuk konsep interpretasi data geolistrik. Hasil investigasi ini secara 


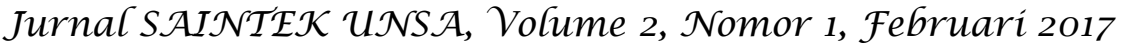

umum juga akan sangat membantu menentukan titik-titikpengukuran geolistrik, karena secara teknis jarak antara titik pengukuran tidak linier terhadap jarak melainkan sangat tergantung pada kondisi geologi dan hidro-geologi setempat.

c.Pengukuran Geolistrik dan

Pengeplotan Data di Lapangan

1) Survei Geolistrik

Cara Vertikal electrical sounding

(VES) dapat dipakai dalam penentuan kedalaman batuan dasar, penyelidikan potensi sumber bahan.

2) Metode

Metode konfigurasi pengukuran geolistrik ada beberapa macam antara lain: Schlumberger, Wenner, Three Electrode Schlumberger, Three Electrode Wenner dan Azimuthal Dipole.

Penentuan titik pengukuran didasarkan pada analisis peta geologi dan hidro-geologi daerah penelitian. Setelah didapatkan analisis geologi dan hidro-geologi daerah penelitian, dilakukan penetapan titik duga geolistriknya. Pada studi ini pendugaan hambatan jenis semu dilakukan dengan konfigurasi Schlumberger. Data yang harus dicatat dalam setiap lokasi titik pengukuran geolistrik adalah:

a) Nomor titik pengukuran, wilayah administrasi (desa)

b) Posisi geografis titik pengukuran dengan GPS

c) Jarak antar elektroda pada posisi konfigurasi (meter)

d) Bacaan potensial (Volt), arus (Ampere) dan hambatan (ohm)

Selain itu juga dilakukan pengukuran kedalaman muka air tanah dengan menggunakan rollmeter. Pengukuran muka air tanah dilakukan pada sumur gali yang dianggap mewakili daerah sekitarnya.
1)Pelaksanaan Pengukuran Geolistrik

Pengukuran geolistrik di lapangan menggunakan beberapa sistem dengan Rangkaian elektroda Schlumberger, dengan ketentuan sebagai berikut:

a) Titik elektroda "Potensial" dengan kode $M$ \& $N$ dan titik elektroda "Arus" dengankode A \& B.

b) Panjang kabel-kabel untuk elektroda "Arus" ( $A B / 2)$, minimal 100 meter.

c) Nilai tegangan arus potensial agar selalu diusahakan minimal 1 volt, dengan caramengubah/memperbesar curve pada kertas grafik log-log.

d) Lintasan bentangan kabel elektroda selama pengukuran, diusahakan selalu sejajardengan jurus (strike) lapisan batuan dan posisi titik elektroda (A.B.M.N) berada dalam satu garis lurus.

e) Titik duga/pengukuran harus diupayakan jauh dari bangunan/ jembatanberkerangka baja, jalur listrik bertegangan tinggi, genangan-genangan air, saluran, sungai dan lain-lain.

f) Jarak pengukuran dari garis pantai minimal 250 meter.

g) Metode pengukuran dan jarak, pada setiap titik pengukuran harus selalu konsisten.

h) Sebelum dilakukan pengukuran hubungan kabel-kabel instalasi instrumen harusselalu dicek lewat ground (tanah) dengan menunjukkan hasil baik.

i) Apabila terjadi gangguan teknik dalam pengukuran, pengukuran tidak boleh dilanjutkan dan harus diulang kembali setelah unit peralatan berfungsi normalkembali. 


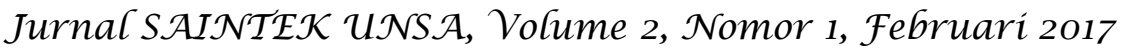

\section{Tahap Analisis dan Interpretasi Data}

a. Analisa Data Pengukuran

Dalam melakukan analisis data hasil pengukuran dan interpretasinya dilakukan dengan menggunakan software IPI2Win pada pengolahan data kali ini, yangnantinya akan menghasilkan nilai (tahanan jenis dalam Ohm meter), h (jangkauan kedalaman dalam meter), d (ketebalan suatu lapisan dalam meter), dan Alt (nilai minus dari nilai $h$ ). Memasukkan data ke dalam software, langkahnya :

1) Open file atau klik "F3",

2) Memilih konfigurasi (Schlumberger),

3) Memilih input data yang hanya membutuhkan nilai $A B / 2, M N$, dan $\mathrm{R}$, karenaalat yang dipakai sudah langsung dapat membaca nilai " $R$ ", sehingga kitatidak perlu memasukkan nilai SP, V, I untuk mendapatkan nilai $\mathrm{K}$ lalu nilai $\mathrm{R}$.

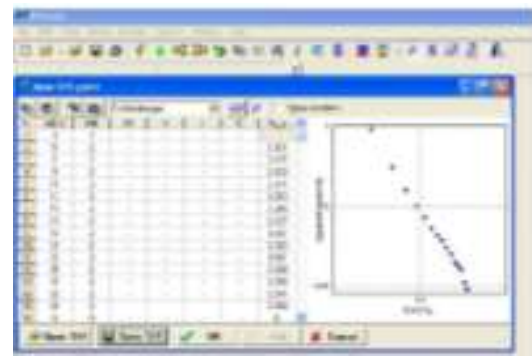

4) Di save TXT, klik OK.

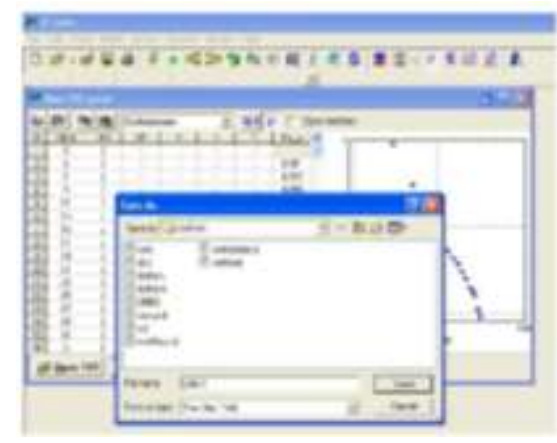

5) Di save dalam IPI format, klik save lalu akan muncul grafik hasilnya, yang disertai dengan nilai $h, d$, dan Alt, grafik yang didapat, diusahakan untuk mencapai kesalahan relatif sekecil mungkin.

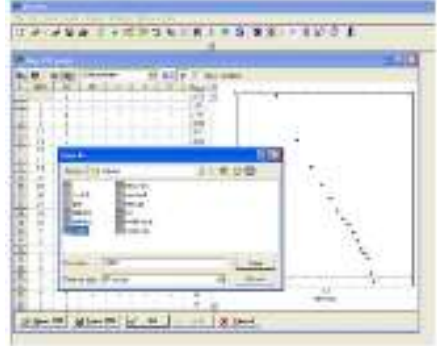

6) Pengolahan data hasil survey atau pengukuran geolistrik dilakukan secara :

a) bertahap, mulai dari perhitungan untuk setiap titik pengukuran (sounding),

b) korelasi antar titik pengkuran (pseodosection, interpretasi jenis batuan dari

c) data resistivitas, dan pembuatan profil geologi dari data survey geolistrik.

d) Dari profil geologi yang dibuat dapat direkomendasikan titik pemboran dan kedalamannya.

b. Analisis titik pengukuran (sounding)

Berdasarkan data hasil survey geolistrik, pengolahan data dilakukan dengan menggunakan metode fitting curve automatic invertion untuk memperoleh nilaiVES (Vertical Electrical Sounding). Nilai masukan yang dilakukan berasal dari spasi elektroda $(A B / 2),(M N)$, serta masukan nilai resistivitas semu (Apparentresistivity) yang dihitung berdasarkan persamaan :

$\rho_{a}=\pi\left[\left(\frac{(A B / 2)^{2}}{M N}\right)-\left(\frac{M N}{4}\right)\right](\Omega m)$

Data hasil pengukuran lapangan dengan konfigurasi schlumberger dianalisis dengan menggunakan software Progress 3, kemudian diuji ulang denganIP2WIN. Apabila dari analisis kedua software tersebut tidak menunjukkan perbedaan yang berarti, maka proses analisis selanjutnya dilakukan.Untuk mendapatkan nilai resistivitas yang sebenarnya dilakukan 


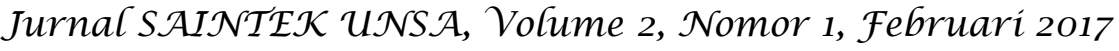

iterasi pada nilai masukan sehingga didapatkan nilai kedalaman dalam meter dan nilai resistivitas untuk masing-masing lapisan. Iterasi dilakukan hingga mencapai fitting terbaik antara kurva lapangan dengan kurva model (teori) dengan nilai kesalahan (RMS yaitu Root Mean Square) terkecil. Data Hasil pengukuran dan perhitungannya dengan program Progress 3. Dari perhitungan tahap ini dihasilkan:

1) Nilai tahanan jenis dari tiap-tiap lapisan

2) Ketebalan dan kedalaman lapisan.

c. Korelasi antar titik pengukuran (pseudosection)

Pemodelan lapisan bawah permukaan dapat dilakukan dengan mengkorelasikan antar titik pengukuran (sounding) yang telah diketahui hambatan jenis setiap lapisannya, sehingga dihasilkan profil hambatan jenis (pseudosection). Data yang telah diperoleh dari setiap titik sounding diolah dengan menggunakan software IP2WIN, sehingga dihasilkan gambaran dua dimensi lapisan bawah permukaan. Dengan mengetahui sebaran nilai hambatan jenis setiap lapisan, maka akan memudahka interpretasi model geologinya baik secara vertikal maupun horisontal.

d. Interpretasi Jenis Batuan

Untuk membuat model kondisi geologi bawah permukaan, termasuk keberadaan lapisan pembawa air, hasil perhitungan data geolistrik yang berupa perlapisan dan resistivitas semu perlu diterjemahkan menjadi perlapisan dan jenis batuan terlebih dahulu, Interpretasi data berupa penentuan kedalaman, ketebalan lapisan, serta tahanan jenis yang dikorelasikan dengan keadaan Geologi lokal. Selain itu, dalam menginterpretasikan data tersebut juga dibutuhkan pemahaman geologi dan hidro-geologi regional daerah setempat, dan akan lebih baik apabila ada hasil pemboran yang pernah dilakukan disekitar lokasi. e. Pembuatan Profil Geologi

Profil geologi dibuat dengan mengkorelasikan lapisan yang mempunyai kesamaan jenis batuan dan strutur geologi yang logis, juga disesuaikan dengan hasil korelasi antar titik sounding (pseudosection). Pembuatan Profil atau Penampang Melintang Beberapa ketentuan yang perlu diperhatikan dalam pembuatan profil hasil pengukuran geolistrik antara lain:

1) Penggambaran peta situasi dan titik lokasi pengukuran dengan skala 1:50.000 atau lebih besar. Titik patok harus digambarkan dalam peta lokasi lengkap dengan koordinat dan elevasi/ketinggian, lokasi dari level garis pantai/muka laut.

2) Profil atau sayatan melintang hasil korelasi data geolistrik disajikan sedemikian rupa, sehingga dapat memberikan gambaran struktur bawah permukaan.

3) Dalam membuat korelasi juga mencerminkan beda tinggi topografi masing-masing titik lokasi.

4) Dalam pembuatan korelasi/cross section apabila melintasi titik sumur bor, maka sayatan litologi sumur harus digambarkan pula.

5) Penampang korelasi geologi/cross section dibuat dalam dua arah, yakni sejajar jurusan lapisan batuan (sejajar strike) dan sejajar kemiringan lapisan batuan (tegak lurus strike/sejajar dip).

\section{ANALISIS DAN PEMBAHASAN Interpretasi Geologi}

Morfologi lokasi pengukuran berupa dataran pantai yang terletak tepat dikaki perbukitan. Dengan kondisi geologi tersusun oleh Satuan Breksi-Tuf yaitu batuan breksi yang bersifat andesit, dengan sisipan tuf pasiran, tuf batu apung dan batu pasir tufaan, setempat mengandung lahar, lava andesit dan basal. Umumnya kelabu kehijauan dan hijau 


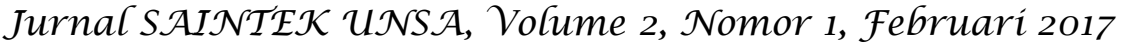

dengan umur satuan yang menunjukkan Miosen, didasarkan atas umur fosil (Kadar 1972, komunikasi tertulis) yang terdapat dalam lensa batu gamping (Tml). Satuan Breksi-Tuf ini menjemari dengan Satuan Batu pasir Tufan (Tms) dan juga Satuan Batu Gamping (Tml). Secara tidak selaras mengalasi Satuan Batu Gamping Koral (Tmcl).

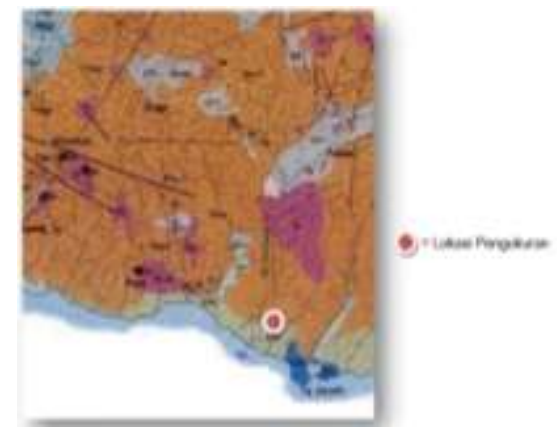

Gambar 3. Kondisi Geologi

Regional Daerah Pengukuran Berdasarkan Morfologi

Berdasarkan susunan batuannya seperti disebutkan diatas, kondisi hidrogeologi daerah pengukuran tergolong dalam sistem akuifer bercelah atau sarang, dengan produktifitas kecil, setempat berarti yaitu umumnya keterusan sangat rendah, setempat air tanah dangkal dalam jumlah terbatas dapat diperoleh pada zona pelapukan dari batuan padu.

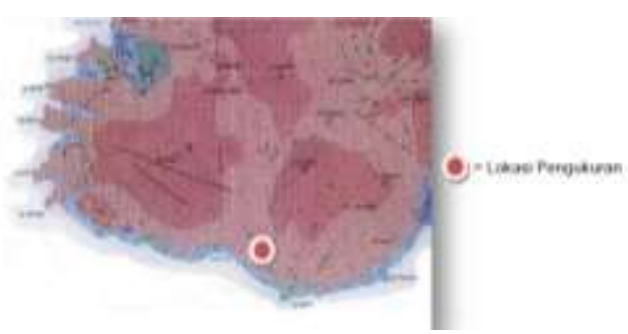

Gambar 4. Kondisi Geologi

Regional Daerah Pengukuran berdasarkan Susunan Batuannya

\section{Hasil Pengukuran Geolistrik}

\section{Hasil Pengukuran Dusun A}

Titik pengukuran geolistrik untuk wilayah dusun $A$ dapat dilihat pada Tabel 4 dibawah ini.
Tabel 4. Lokasi Titik Pengukuran Geolistrik Dusun A

\begin{tabular}{|c|c|c|c|c|}
\hline \multirow{2}{*}{ No. } & \multirow{2}{*}{ Dusun } & \multirow{2}{*}{ Titik } & \multicolumn{2}{|c|}{ Koordinat (UTM) } \\
\cline { 4 - 5 } & & & $X$ & $Y$ \\
\hline 1 & \multirow{3}{*}{$\mathrm{A}$} & 1 & 498750,90 & 8997102,91 \\
\cline { 4 - 5 } & & 2 & 498716,09 & 8997139,76 \\
\hline 3 & & 3 & 498815,00 & 8996984,98 \\
\hline & & & & \\
\hline
\end{tabular}

Penetrasi kedalaman sounding untuk 3 (tiga) pengukuran geolistrik di Dusun A adalah $100 \mathrm{~m}(\mathrm{AB} / 2)$ dengan panjang bentangan $200 \mathrm{~m}$.

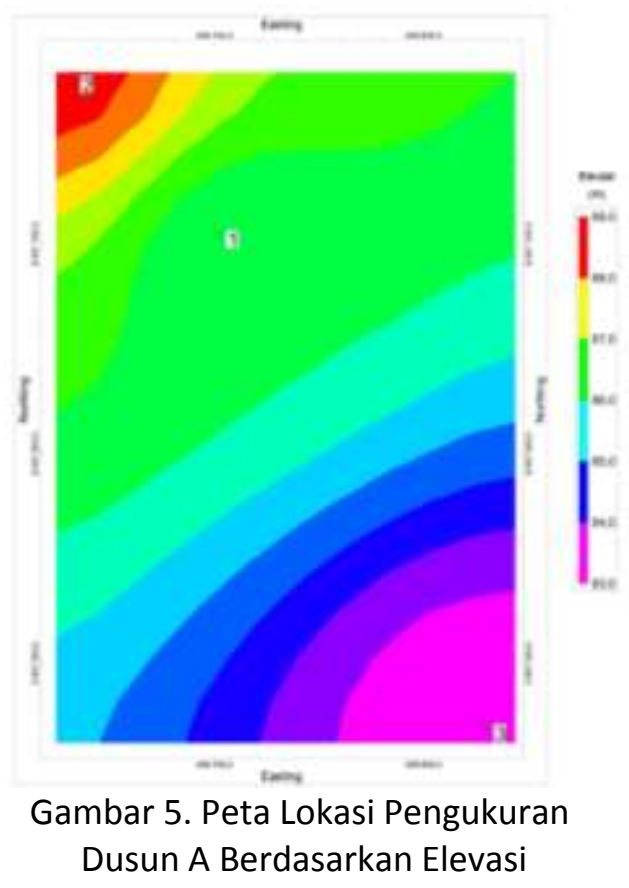

Hasil Inversi Software IP2WIN Dosen A: 


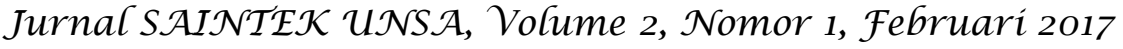

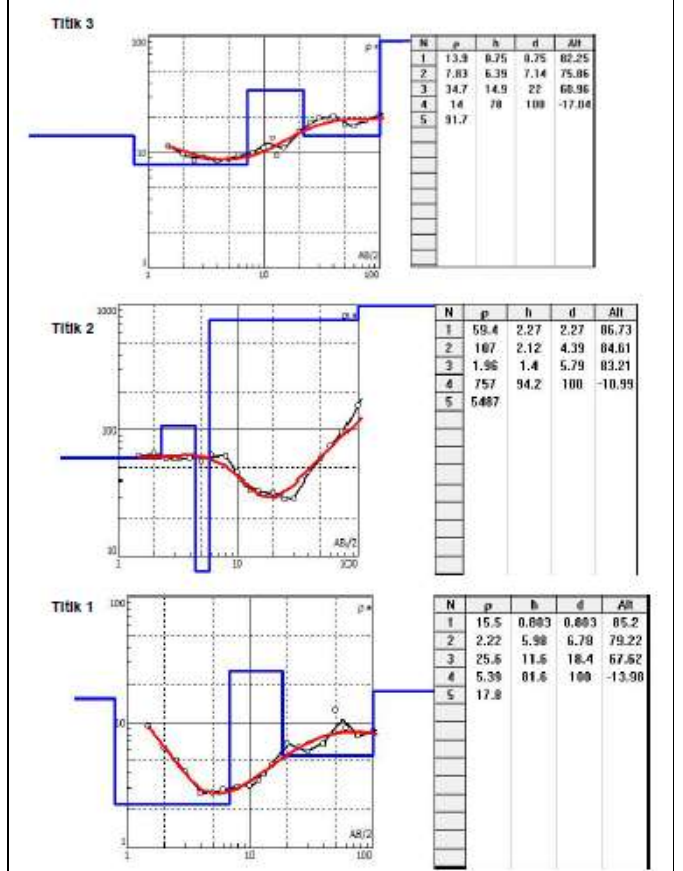

Gambar 6. Hasil Inversi Bantuan Software IP2WIN Untuk Dusun A

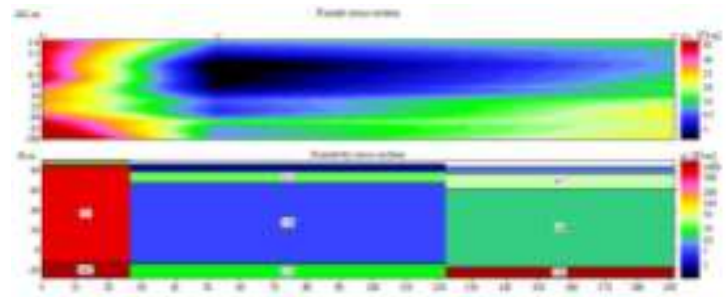

Gambar 7. Penampang Melintang Resistivitas Antar Titik Pengukuran Dusun A

Dari hasil inversi diatas berdasarkan gambar 5 hingga gambar 7 menunjukkan bahwa diperoleh nilai tahanan jenis sebenarnya dengan errors $=8,76 \mathrm{~s} / \mathrm{d} 13,6$ $\%$ masih dibawah $15 \%$ sehingga dapat disimpulkan struktur lapisan dibawah permukaan tanah berdasarkan nilai tahanan jenisnya sebagai berikut :

Tabel 5. Hasil Inversi Titik 1 Dusun A

\begin{tabular}{|c|c|c|c|c|c|}
\hline $\begin{array}{l}\text { Lpisa } \\
\text { n }\end{array}$ & $p(0 m)$ & $\begin{array}{l}\text { Ketebalan } \\
\text { (m) }\end{array}$ & $\begin{array}{l}\text { Kedataman } \\
\text { (m) }\end{array}$ & Litologi & $\begin{array}{c}\text { Pote } \\
\text { nsi }\end{array}$ \\
\hline 1 & 15,5 & 0,303 & 0,803 & Alluvium & $Y_{a}$ \\
\hline 2 & 2.22 & 5,98 & 6,78 & Lempung & Tdak \\
\hline 3 & 25,6 & 11,6 & 18,4 & Pasir Tutasn & $y_{2}$ \\
\hline 4 & 5,39 & 31,6 & 100 & Pasie Tufaan & $\gamma_{a}$ \\
\hline 5 & 178 & - & - & Pasir Tufaan & $\gamma_{a}$ \\
\hline
\end{tabular}

Tabel 6. Hasil Inversi Titik 2 Dusun A

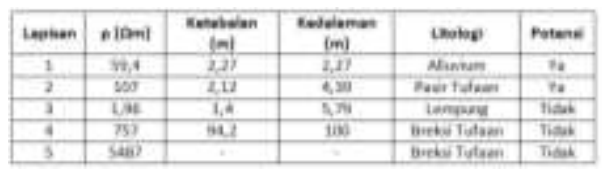

Tabel 7. Hasil Inversi Titik 3 Dusun A

\begin{tabular}{|c|c|c|c|c|c|}
\hline Lepiaen. & $p(\mathrm{Dm})$ & $\begin{array}{c}\text { Kenteistan } \\
\{m]\end{array}$ & $\begin{array}{c}\text { Kedalaman } \\
(m)\end{array}$ & Uhology & poten: \\
\hline 1 & 13,0 & $a, 75$ & a.rs & Nhaviam & Ya \\
\hline 2 & 7,93 & 6,35 & 7,14 & Dasctuanen & ra \\
\hline 3 & 34,7 & 149 & $n$ & Pasr Tifaen & Ya \\
\hline$\pi$ & 14 & 78 & 100 & Pasr Tifaen & $y_{0}$ \\
\hline 5 & 31,7 & + & - & Pase Tifain & $r_{a}$ \\
\hline
\end{tabular}

Berdasarkan hasil inversi seperti gambar 6 dan gambar 7 serta tabel 5 hingga tabel 7 diatas, pola sebaran akuifer dari arah utara menuju selatan dengan titik pengukuran 3 (tiga) merupakan titik yang direkomendasikan untuk dikembangkan sebagai sumur dalam. Karakteristik akuifer didaerah ini berdasarkan nilai tahanan jenis dan struktur lapisan bawah tanah merupakan akuifer setempat yang dipengaruhi oleh musim.

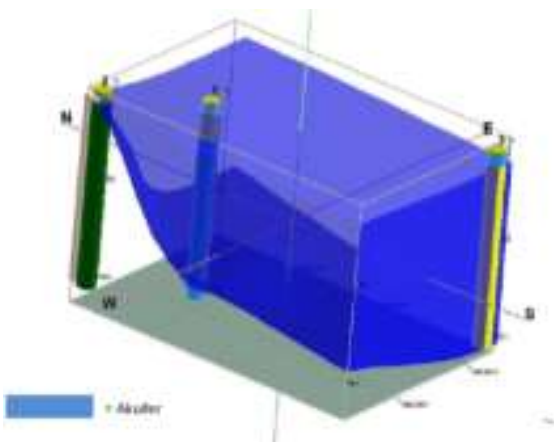

Gambar 8. Sebaran Akuifer Dusun A

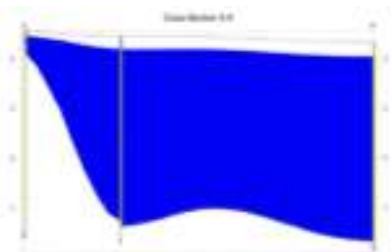

Gambar 9. Profil Memanjang (Titik 2-1-3) Akuifer Dusun A 


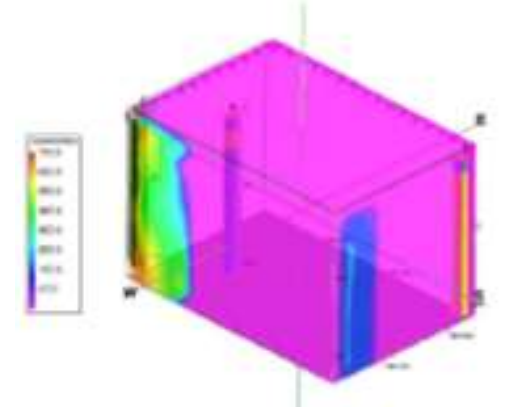

Gambar 10. Tahanan Jenis

Pengukuran Geolistrik Dusun A

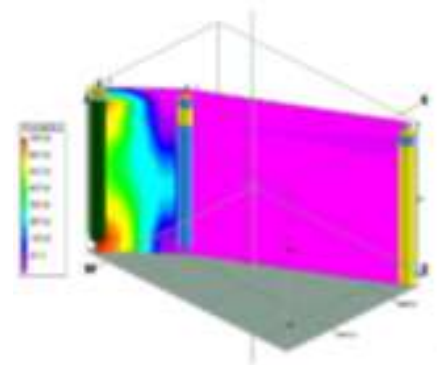

Gambar 11. Profil Memanjang Tahanan Jenis (Titik 2-1-3) Dusun A

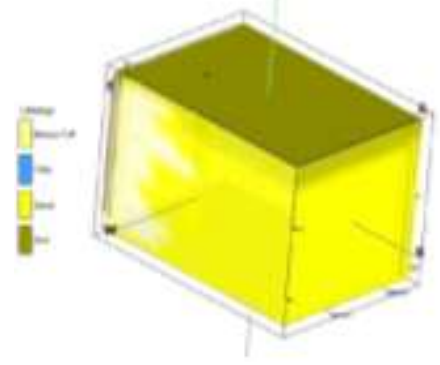

Gambar 12. Litologi Lokasi Pengukuran Dusun A

\section{Hasil Pengukuran Dusun B}

Titik pengukuran geolistrik untuk wilayah dusun B dapat dilihat pada Tabel 8 dibawah ini.

Tabel 8. Lokasi Titik Pengukuran Geolistrik Dusun B

\begin{tabular}{|c|c|c|c|c|}
\hline \multirow{2}{*}{$\begin{array}{c}\text { N } \\
\text { o }\end{array}$} & \multirow{2}{*}{$\begin{array}{c}\text { Dus } \\
\text { un }\end{array}$} & \multirow{2}{*}{ Titik } & \multicolumn{2}{|c|}{ Koordinat (UTM) } \\
\cline { 4 - 5 } & & & $\mathrm{X}$ & $\mathrm{Y}$ \\
\hline 1 & \multirow{3}{*}{$\mathrm{B}$} & 1 & 498452,35 & 8997279,79 \\
\cline { 4 - 5 } 2 & 2 & 498417,56 & 8997054,99 \\
\hline 3 & & 3 & 498481,66 & 8996966,54 \\
\cline { 4 - 5 } & & & & \\
\hline
\end{tabular}

Penetrasi kedalaman sounding untuk 3 (tiga) pengukuran geolistrik di Dusun $B$ adalah $85 \mathrm{~m}(A B / 2)$ dengan panjang bentangan $170 \mathrm{~m}$. Adapun hasil pengukuran geolistrik disajikan dalam Lampiran 2.

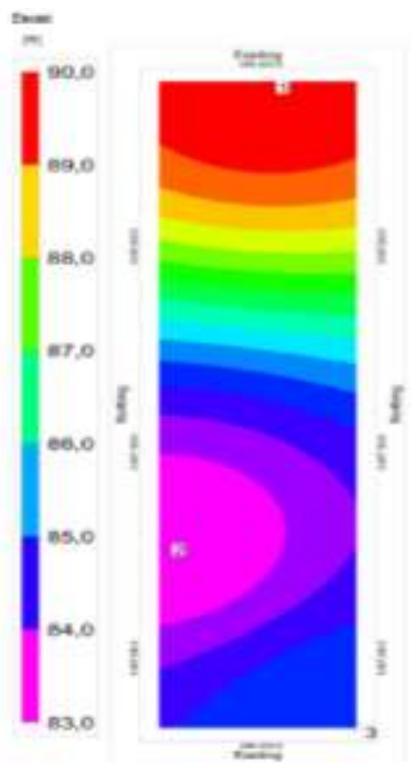

Gambar 13. Peta Lokasi Pengukuran Dusun B Berdasarkan Elevasi

\section{Hasil Inversi Software IP2WIN Dusun B :}

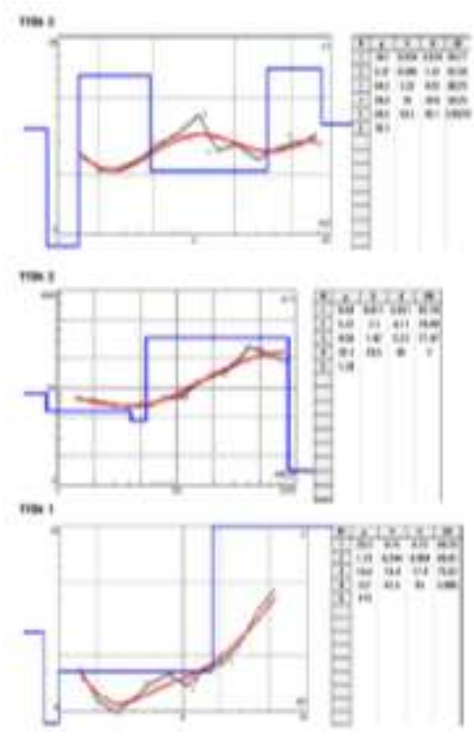

Gambar 14. Hasil Inversi Bantuan Software IP2WIN Untuk Dusun B 


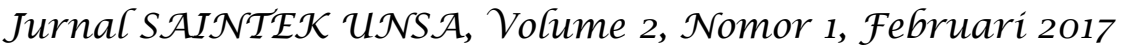

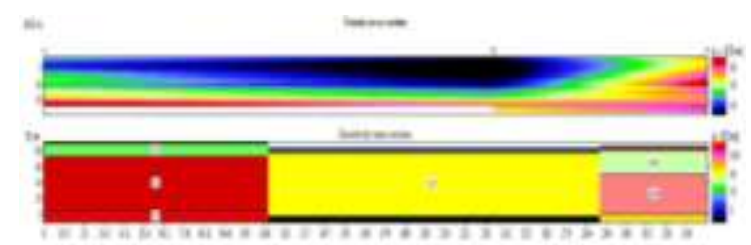

Gambar 15. Penampang Melintang Resistivitas Antar Titik Pengukuran Untuk Dusun B

Dari hasil inversi diatas berdasarkan gambar 13 hingga gambar 15, menunjukkan bahwa diperoleh nilai tahanan jenis sebenarnya dengan errors $=9,06 \mathrm{~s} / \mathrm{d} 10,6 \%$ masih dibawah $15 \%$ sehingga dapat disimpulkan struktur lapisan dibawah permukaan tanah berdasarkan nilai tahanan jenisnya sebagai berikut :

Tabel 9. Hasil Inversi

Titik 1 Dusun B

\begin{tabular}{|c|c|c|c|c|c|}
\hline Lepiesen & - [nam\} & $\begin{array}{c}\text { Kentebeven } \\
\text { (m) }\end{array}$ & $\begin{array}{c}\text { cederemen } \\
(\mathrm{m})\end{array}$ & Lateingl & Patene \\
\hline 1 & $x s$ & 0,0 & an & Nabsian & $v_{n}$ \\
\hline$z$ & $1, \pi$ & 0,244 & Inver & texpre & Fatak \\
\hline 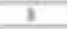 & 16,6 & 144 & $10, a$ & Pase fucean & $n$ \\
\hline 4 & $m$ & 63,6 & $n$ & $\begin{array}{c}\text { hatufner } \\
\text { Mapen }\end{array}$ & Thas \\
\hline 3 & 100 & 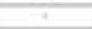 & 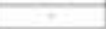 & Beicholean & $F_{n}$ \\
\hline
\end{tabular}

Tabel 10. Hasil Inversi

Titik 2 Dusun B

\begin{tabular}{|c|c|c|c|c|c|}
\hline Lotuen & $(\hat{n})$ & $\begin{array}{c}\text { Ketabalas } \\
(m)\end{array}$ & $\begin{array}{c}\text { Kedaleman } \\
{[\mathrm{m}]}\end{array}$ & Inalos: & Foten: \\
\hline 1 & 269 & oxis & Q611 & Aluien & $\mathrm{m}$ \\
\hline 2 & $5, n$ & 20 & 411 & Intware & That \\
\hline 3 & 4.56 & 1.42 & 553 & tenevers & That \\
\hline 4 & 32,7 & 725 & 6 & Whir Tuton & $m$ \\
\hline 5 & $1 . n$ & + & 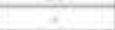 & Inomere & That \\
\hline
\end{tabular}

Tabel 11. Hasil Inversi

Titik 3 Dusun B

\begin{tabular}{|c|c|c|c|c|c|}
\hline Lapisan & $\Leftrightarrow$ & $\begin{array}{l}\text { Ertebalan } \\
\text { (idi) }\end{array}$ & Entilam & Utatosy & Matens \\
\hline 3 & 341 & Dis34 & 2034 & Allunion & $7 a$ \\
\hline 2 & 63 & osas & 19 & terspess & Triset \\
\hline 3 & 643 & 343 & $4 \pi$ & Forrtikin & To \\
\hline 4 & nes & 10 & Ha & Pare nufas & $\mathrm{Va}$ \\
\hline 5 & 636 & 501 & is & merthess & $v_{0}$ \\
\hline 6 & 363 & + & . & Fnet fulas & 7 \\
\hline
\end{tabular}

Berdasarkan hasil inversi seperti gambar 13 hingga gambar 15 serta tabel 9 hingga tabel 11 diatas, pola sebaran akuifer dari arah utara menuju selatan dengan titik pengukuran 3 (tiga) merupakan titik yang direkomendasikan untuk dikembangkan sebagai sumur dalam. Karakteristik akuifer didaerah ini berdasarkan nilai tahanan jenis dan struktur lapisan bawah tanah merupakan akuifer setempat yang dipengaruhi oleh musim.

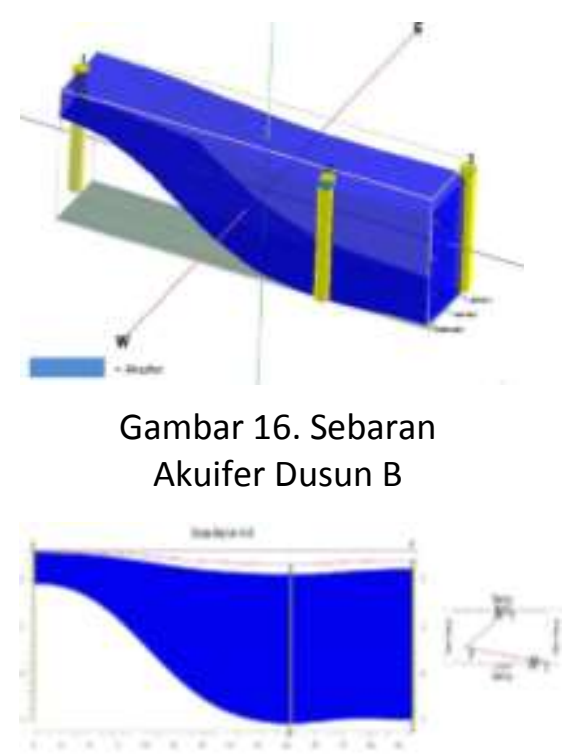

Gambar 17. Profil Memanjang

(1-2-3) Akuifer Dusun B

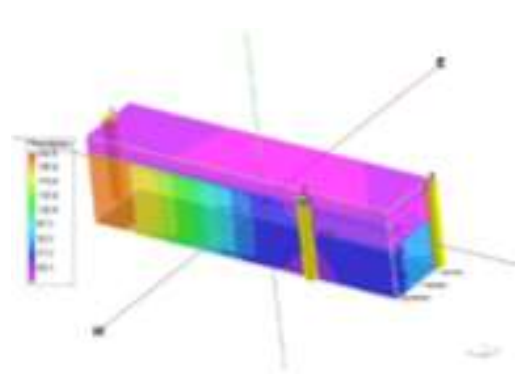

Gambar 18. Tahanan Jenis Pengukuran Geolistrik Dusun B

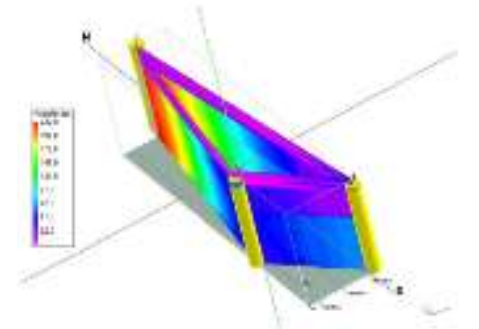

Gambar 19. Profil Memanjang Tahanan Jenis (Titik 1-2-3) Untuk Dusun B 


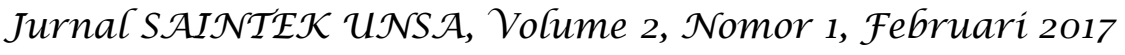

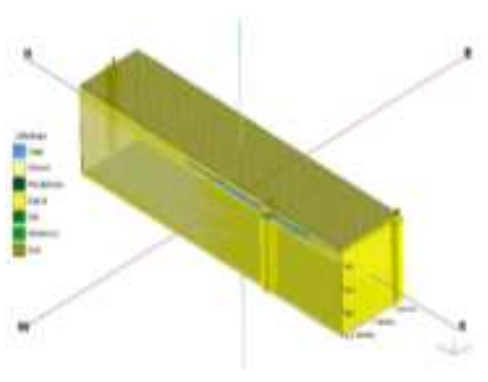

Gambar 20. Litologi Lokasi

Pengukuran Dusun B

\section{Hasil Pengukuran Dusun C}

Titik pengukuran geolistrik untuk wilayah dusun $\mathrm{C}$ dapat dilihat pada Tabel 12 dibawah ini.

Tabel 12. Lokasi Titik

Pengukuran Geolistrik Dusun C

\begin{tabular}{|c|c|c|c|c|}
\hline \multirow{2}{*}{ No. } & \multirow{2}{*}{ Dusun } & \multirow{2}{*}{ Titik } & \multicolumn{2}{|c|}{ Koordinat (UTM) } \\
\cline { 4 - 5 } & & & $X$ & $Y$ \\
\hline 1 & \multirow{2}{*}{$\mathrm{C}$} & 1 & 498093,36 & 8997362,69 \\
\cline { 4 - 5 } & & 2 & 498417,56 & 8997270,56 \\
\hline 3 & & 3 & 498481,66 & 8997379,26 \\
\hline
\end{tabular}

Penetrasi kedalaman sounding untuk 3 (tiga) pengukuran geolistrik di Dusun $C$ adalah $100 \mathrm{~m}(\mathrm{AB} / 2)$ dengan panjang bentangan $200 \mathrm{~m}$.

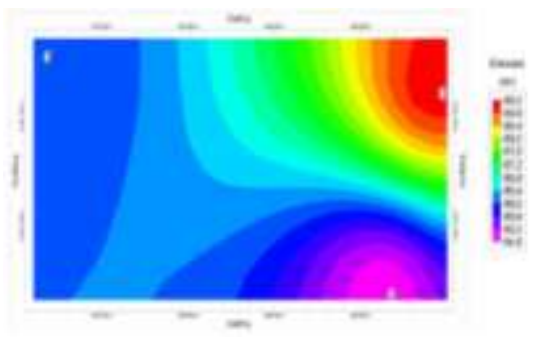

Gambar 21. Peta Lokasi Pengukuran Dusun C Berdasarkan Elevasi

\section{Hasil Inversi Software IP2WIN Dusun C :}
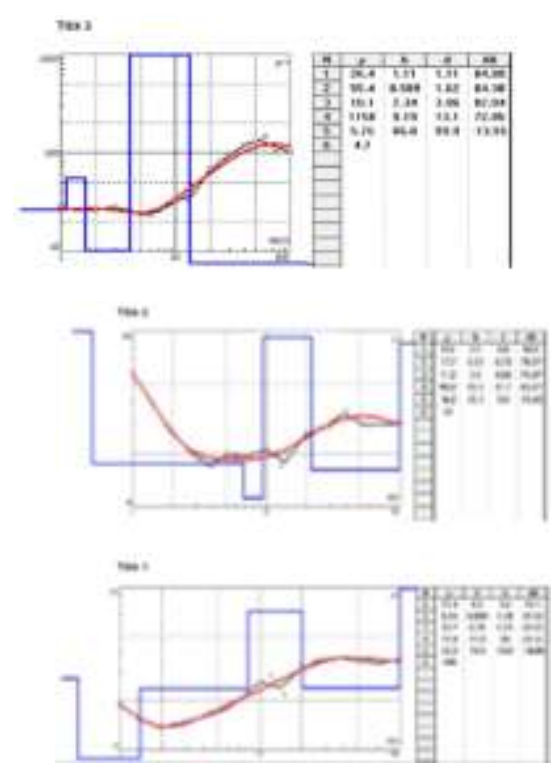

Gambar 22. Hasil Inversi Bantuan Software IP2WIN Untuk Dusun C

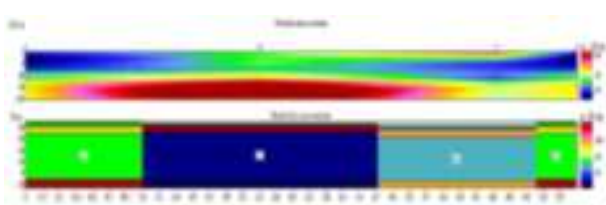

Gambar 23. Penampang Melintang Resistivitas Antar Titik Pengukuran Untuk Dusun C

Dari hasil inversi diatas berdasarkan gambar 21 hingga gambar 23, menunjukkan bahwa diperoleh nilai tahanan jenis sebenarnya dengan errors = 4,96 s/d 9,64 \% masih dibawah $15 \%$ sehingga dapat disimpulkan struktur lapisan dibawah permukaan tanah berdasarkan nilai tahanan jenisnya sebagai berikut :

Tabel 13. Hasil Inversi

Titik 1 Dusun C

\begin{tabular}{|c|c|c|c|c|c|}
\hline Lapiuen & $(\overrightarrow{0})$ & $\begin{array}{c}\text { Cotabeikn } \\
\text { (in) }\end{array}$ & $\begin{array}{l}\text { Molotimen } \\
\text { (m) }\end{array}$ & Uatos & Potens. \\
\hline 3 & $2 n / 4$ & Q.s & a.s & Douit Tavin & ro \\
\hline 2 & 2,40 & 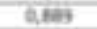 & 253 & tancers & Trabe \\
\hline 3 & 211 & 5.8 & 815 & ministom & 7 \\
\hline 4 & 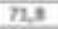 & II, 9 & Do & Pourtuan & $n$ \\
\hline 3 & 213 & $n, 0$ & 100 & Don't wawn & $\gamma_{*}$ \\
\hline 5 & 200 & 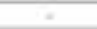 & $=$ & 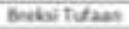 & $\mathrm{n}$ \\
\hline
\end{tabular}


Tabel 14. Hasil Inversi

Titik 2 Dusun C

\begin{tabular}{|c|c|c|c|c|c|}
\hline Laplaan & $\left|a^{0}\right|$ & $\begin{array}{c}\text { Kertabelan } \\
\text { (m) }\end{array}$ & $\begin{array}{c}\text { Ketalaman } \\
(m)\end{array}$ & Litolog! & Potenat \\
\hline 1 & 100 & 0,5 & $Q 5$ & Dris Tufaten & $V_{i}$ \\
\hline 2 & 17,7 & 6,23 & 673 & Pasie futaan & $y_{n}$ \\
\hline 3 & $\pi 1,2$ & 2.8 & 953 & Paser fufan & $y_{n}$ \\
\hline 4 & 93,2 & 12,2 & 217 & Penr Tutaum & $n_{n}$ \\
\hline 5 & 10,2 & $7 n 3$ & 100 & Pnir fufasen & $n$ \\
\hline 5 & 整 & + & + & Paik Futasen & 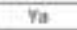 \\
\hline
\end{tabular}

Tabel 15. Hasil Inversi

Titik 3 Dusun C

\begin{tabular}{|c|c|c|c|c|c|}
\hline Laplaan & $(\overrightarrow{a m})$ & $\begin{array}{l}\text { Kotebasam } \\
\text { (m) }\end{array}$ & $\begin{array}{c}\text { Kodalaman } \\
{[\mathrm{m}]}\end{array}$ & Lteloy & Patenai \\
\hline 1 & 26,4 & 1,11 & III & Probir Thisan & $r a$ \\
\hline 2 & 35,4 & 9509 & 1,02 & Pair tofson & 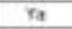 \\
\hline 3 & 101 & 234 & 196 & Penr Tufan & $n$ \\
\hline 4 & $\$ 150$ & 219 & 13,1 & $\begin{array}{l}\text { Erebibitulaan } \\
\text { Kompet }\end{array}$ & Tidas: \\
\hline 5 & $5,7 \%$ & 86,8 & 100 & tempoing & Tidater \\
\hline 6 & 4.7 & - & - & tenpring & Tident \\
\hline
\end{tabular}

Berdasarkan hasil inversi seperti gambar 21 hingga gambar 23 serta tabel 13 hingga tabel 15 diatas, pola sebaran akuifer dari arah barat menuju timur dengan titik pengukuran 2 (dua) merupakan titik yang direkomendasikan untuk dikembangkan sebagai sumur dalam. Karakteristik akuifer didaerah ini berdasarkan nilai tahanan jenis dan struktur lapisan bawah tanah merupakan akuifer setempat yang dipengaruhi oleh musim.

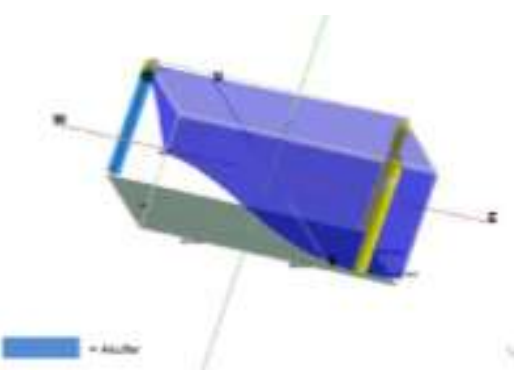

Gambar 24. Sebaran

Akuifer Dusun C

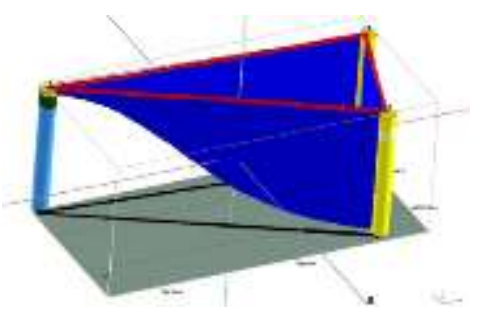

Gambar 25. Profil Memanjang (1-2-3) Akuifer Dusun C

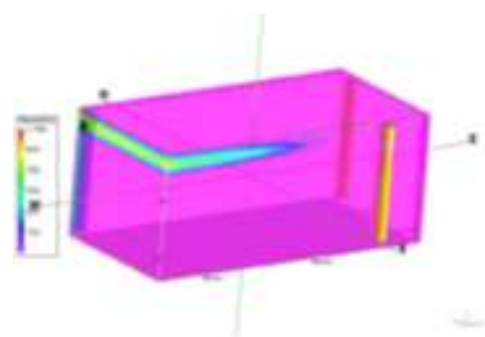

Gambat 26. Tahanan Jenis Pengukuran Geolistrik Dusun C

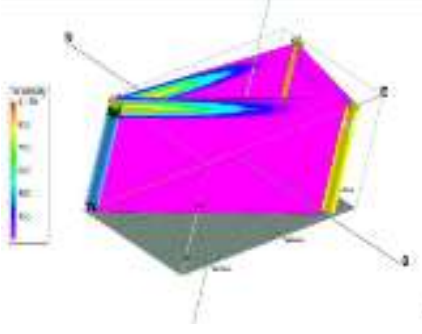

Gambar 27. Profil Memanjang Tahanan Jenis (Titik 1-2-3) Untuk Dusun C

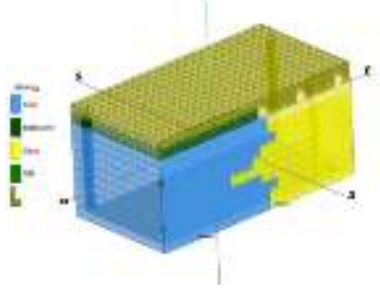

Gambar 28. Litologi Lokasi Pengukuran Dusun C

\section{KESIMPULAN}

Dari hasil Kajian Potensi Air Tanah Dengan Pengujian Geolistrik Di Desa Telonang Kabupaten Sumbawa Barat dengan metode tahanan jenis guna mengetahui potensi akuifer untuk pemanfaatan air tanah dapat ditarik kesimpulana sebagai berikut :

1. Zona 1 (Dusun A) batuan yang berpotensi sebagai akuifer adalah pasir tufaan dengan titik pengukuran $\mathbf{3}$ adalah lokasi yang memiliki potensi lebih besar dari pada titik lainnya. Karakteristik akuifer didaerah ini adalah akuifer setempat yang dipengaruhi oleh musim.

2. Zona 2 (Dusun B) batuan yang berpotensi sebagai akuifer adalah pasir tufaan dengan titik pengukuran $\mathbf{3}$ adalah lokasi yang 


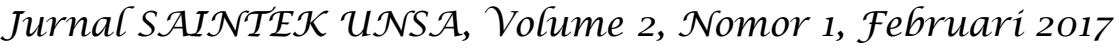

memiliki potensi lebih besar dari pada titik lainnya. Karakteristik akuifer didaerah ini adalah akuifer setempat yang dipengaruhi oleh musim.

3. Zona 3 (Dusun $\mathrm{C}$ ) batuan yang berpotensi sebagai akuifer adalah pasir tufaan dengan titik pengukuran 2 adalah lokasi yang memiliki potensi lebih besar dari pada titik lainnya. Karakteristik akuifer didaerah ini adalah akuifer setempat yang dipengaruhi oleh musim.

\section{Saran}

Berdasarkan pertimbangan nilai tahanan jenis, interpretasi geologi regional setempat dan daerah tangkapan air, untuk kedalaman pengeboran dari kedalaman $50-100 \mathrm{~m}$ dan pemanfaatan air tanah hanya untuk keperluan air baku $( \pm 5,00 \mathrm{l} / \mathrm{dt})$.

\section{DAFTAR PUSTAKA}

Adhyl. 2015. Keberadaan Dan Klasifikasi Air Tanah. Di Akses : 6 April 2016

http://ideageografer.blogspot.co.id/2015/04/ keberadaan-dan-klasifikasi-airtanah.html.

Anonim, 2010. Kondisi Topografi Wilayah KSB Tahun 2009, BPS dan BAPPEDA, Kabupaten Sumbawa Barat.

Anonim, 2016. Kebutuhan Air Irigasi, Dinas Pekerjaan Umum Pusat. http://www.pu.go.id/uploads/services infopublik20120703114708.pdf. Di Akses : 26 April 2016.

Anonim, 2016. Siklus Hidrologi dan Jenis Perairan, PT. Phibeta Aneka Gama, http://www. siklus-hidrologi-danjenis-perairan.html. Di Akses : 26 April 2016.

Ardhana, Rika. 2013. Air Tanah. Di Akses : 6 April 2016 http://rinesaa.blogspot.co.id/2013/11 Lair-tanah.html
Kusmajaya, Febrian. 2015. Pengukuran Geolistrik Untuk Penentuan Detail Lokasi Sumur Bor Di Sumbawa. Nusa Tenggara Barat.

Purnama, A, 2011. STUDI KELAYAKAN PEMBANGUNAN PEMBANGKIT LISTRIK TENAGA MIKROHIDRO Studi Kasus: PLTMH Minggir pada saluran irigasi Minggir di Padukuhan Klagaran Desa Sendangrejo Kecamatan Minggir Kabupaten Sleman, Jurnal Unsa Progress. Vol.10, No.15, Oktober, Universitas Samawa, Sumbawa Besar.

Purnama, A., Badaruddin., dan Haris, A. 2016. PENGEMBANGAN SISTEM JARINGAN AIR BERSIH DENGAN METODE GRAVITASI DI DESA BATU TERING KECAMATAN MOYO HULU, Jurnal Saintek Unsa. Vol.1, No.2, September, Universitas Samawa, Sumbawa Besar. 